\title{
Anti-rheumatic treatment and prosthetic joint infection: an observational study in 494 elective hip and knee arthroplasties
}

\author{
Ylva Borgas ${ }^{1}$, Anders Gülfe ${ }^{1,2}$, Mikael Kindt ${ }^{3}$ and Anna Stefánsdóttir ${ }^{3,4^{*}}$ (D)
}

\begin{abstract}
Background: Surgical site infections are more frequent among patients with rheumatic disease. To what extent this is related to immunosuppressive antirheumatic drugs is unclear, as is the value of discontinuing medication perioperatively. The aim of study was to assess the rate of surgical site infections after knee and hip replacement in patients with inflammatory joint disease, with an emphasis on periprosthetic joint infection, and to investigate the influence of treatment with disease-modifying antirheumatic drugs (DMARDs) in this regard.

Methods: Data were collected from 494 primary elective hip (51.4\%) and knee arthroplasties, along with demographic and medication data. The primary outcome was surgical site infection during the first year after surgery.

Results: In 78\% ( $n=385$ ) of the cases the patient used 1 to 3 disease-modifying antirheumatic drugs perioperatively. Thirty-two percent $(n=157)$ of patients used a TNF-alpha inhibitor. The rate of surgical site infection was 3.8\% ( $n=19)$. The rate of periprosthetic joint infection was $1.4 \%(n=7)$, all of which occurred after knee arthroplasty. Periprosthetic joint infection occurred in only 1 patient medicating perioperatively with a TNF-alpha inhibitor.

Conclusion: Surgical site infections were not associated with ongoing medication with disease-modifying antirheumatic drugs. Due to the low event rate this should be interpreted with caution, but our center will maintain its routine of continuing treatment with TNF-alpha inhibitors perioperatively.
\end{abstract}

Keywords: Infections, Orthopedic surgery, bDMARD, Anti-TNF

\section{Background}

In most affluent countries during the past 20 years, treatment with biologic disease-modifying drugs (bDMARDs) such as TNF-alpha inhibitors has become part of the standard of care for patients with rheumatoid arthritis (RA), as well as for other types of inflammatory joint disease. Although the need for joint arthroplasty in these

\footnotetext{
* Correspondence: anna.stefansdottir@med.lu.se

${ }^{3}$ Department of Orthopaedics, Skåne University Hospital, SE-221 85 Lund, Sweden

${ }^{4}$ Department of Clinical Sciences, Section of Orthopaedics, Lund University, Lund, Sweden

Full list of author information is available at the end of the article
}

patients has decreased [1-7], a number of patients still are admitted to surgery. Many of these patients are treated with conventional disease-modifying drugs (cDMARDs) and/or bDMARDs prior to the operation.

The incidence of infections in general is higher in patients with RA than in non-RA subjects. It is still not fully understood whether this is a consequence of immunologic disturbances due to the disease itself - as disease severity is a risk factor for infection - or of the immunosuppressive treatment often used.

TNF-alpha inhibitors are thought to increase the general risk of infection $[8,9]$. 
Table 1 studies on the influence of biologic DMARDs on SSI rate

\begin{tabular}{|c|c|c|c|c|}
\hline Author, year & Type of surgery & $\begin{array}{l}\text { Number of } \\
\text { operations }\end{array}$ & bDMARD & $\begin{array}{l}\text { Main finding in patients not } \\
\text { stopping bDMARDs }\end{array}$ \\
\hline $\begin{array}{l}\text { Bibbo \& Goldberg, } \\
2004[10]\end{array}$ & Foot and ankle surgery & 31 & Continued treatment perioperatively & SSI rate decreased \\
\hline $\begin{array}{l}\text { Talwalkar et al., } \\
2005[11]\end{array}$ & $\begin{array}{l}\text { Various orthopedic } \\
\text { surgeries }\end{array}$ & 11 & $\begin{array}{l}\text { TNF inhibitors discontinued } 2-4 \text { weeks prior to surgery } \\
\text { or continued treatment perioperatively }\end{array}$ & SSI rate unchanged \\
\hline $\begin{array}{l}\text { Wendling et al., } \\
2005 \text { [12] }\end{array}$ & $\begin{array}{l}\text { Various orthopedic } \\
\text { surgeries }\end{array}$ & 50 & $\begin{array}{l}\text { TNF inhibitors discontinued } 2-4 \text { weeks prior to surgery } \\
\text { or continued treatment perioperatively }\end{array}$ & SSI rate unchanged \\
\hline $\begin{array}{l}\text { Giles et al., } 2006 \\
\text { [13] }\end{array}$ & $\begin{array}{l}\text { Various orthopedic } \\
\text { surgeries }\end{array}$ & 91 & Continued treatment perioperatively & SSI rate increased \\
\hline $\begin{array}{l}\text { Broeder et al., } 2007 \\
\text { [14] }\end{array}$ & $\begin{array}{l}\text { Various orthopedic } \\
\text { surgeries }\end{array}$ & 1219 & $\begin{array}{l}\text { TNF inhibitors discontinued } 4 \mathrm{t} 1 / 2 \text { prior to surgery or } \\
\text { continued treatment perioperatively }\end{array}$ & SSI rate unchanged \\
\hline $\begin{array}{l}\text { Ruyssen-Witrand } \\
\text { et al., } 2007 \text { [15] }\end{array}$ & Various surgeries & 127 & Variable timing for discontinuation prior to surgery & SSI rate unchanged \\
\hline $\begin{array}{l}\text { Gilson et al., } 2010 \\
\text { [16] }\end{array}$ & Total joint replacement & 60 & Cases treated with TNF inhibitors included & SSI rate increased \\
\hline $\begin{array}{l}\text { Kawakami et al., } \\
2010[17]\end{array}$ & $\begin{array}{l}\text { Various orthopedic } \\
\text { surgeries }\end{array}$ & 128 & $\begin{array}{l}\text { TNF inhibitors discontinued } 2-4 \text { weeks prior to surgery } \\
\text { and restarted if no signs of infection }\end{array}$ & SSI rate increased \\
\hline $\begin{array}{l}\text { Suzuki et al., } 2011 \\
\text { [18] }\end{array}$ & Arthroplasties & 1626 & Continued treatment perioperatively & SSI rate increased \\
\hline $\begin{array}{l}\text { Momahara et al., } \\
2011 \text { [19] }\end{array}$ & $\mathrm{THA}^{1}$ and $T K \mathrm{~A}^{2}$ & 420 & $\begin{array}{l}\text { TNF inhibitors discontinued } 2-4 \text { weeks prior to surgery, } \\
\text { cDMARDs continued }\end{array}$ & SSI rate increased \\
\hline $\begin{array}{l}\text { Berthold et al., } \\
2013 \text { [20] }\end{array}$ & $\begin{array}{l}\text { Various orthopedic and } \\
\text { hand surgeries }\end{array}$ & 1596 & $\begin{array}{l}\text { TNF inhibitors discontinued } 2-4 \text { weeks prior to surgery } \\
\text { or continued treatment perioperatively }\end{array}$ & SSI rate increased \\
\hline $\begin{array}{l}\text { Tada et al., } 2016 \\
\text { [21] }\end{array}$ & $\begin{array}{l}\text { Various orthopedic } \\
\text { surgeries }\end{array}$ & 332 & $\begin{array}{l}\text { TNF inhibitors discontinued } 2-4 \text { weeks prior to surgery, } \\
\text { cDMARDs continued }\end{array}$ & SSI rate unchanged \\
\hline $\begin{array}{l}\text { Hayashi et al., } 2017 \\
\text { [22] }\end{array}$ & $\mathrm{THA}^{\mathrm{a}}$ & 99 & $\begin{array}{l}\text { Variable timing for discontinuation or no } \\
\text { discontinuation prior to surgery }\end{array}$ & late SSI rate increased \\
\hline $\begin{array}{l}\text { Salt et al., } 2017 \\
\text { [23] }\end{array}$ & $\begin{array}{l}\text { THA }^{\mathrm{a}}, \mathrm{TKA}^{\mathrm{b}} \text { and total } \\
\text { shoulder arthroplasty }\end{array}$ & 2212 & $\begin{array}{l}\text { Variable timing for discontinuation or no } \\
\text { discontinuation prior to surgery }\end{array}$ & SSI rate unchanged \\
\hline
\end{tabular}

${ }^{\mathrm{a}}$ Total hip arthroplasty, ${ }^{\mathrm{b}}$ Total knee arthroplasty

Studies vary in their findings regarding the risk of postoperative infections in patients taking TNF-alpha inhibitors (Table 1) whereas prior studies suggest that methotrexate is not a substantial risk factor for surgical site infection (SSI) [19, 24].

SSI, and specifically periprosthetic joint infection (PJI), is one of the most serious complications of arthroplasty and a leading cause of early revision [25, 26]. Risk factors for SSI include smoking, diabetes mellitus, obesity, a score $>2$ on the American Society of Anesthesiologists (ASA) Physical Status scale, current infection, and use of steroids [23, 27-30]. Rheumatic disease has been shown to be an independent risk factor for PJI [31-34].

In 2017, the American College of Rheumatology (ACR) published guidelines for the perioperative management of anti-rheumatic medication in patients with rheumatic diseases undergoing elective total hip and total knee arthroplasty. According to these recommendations, TNF-alpha inhibitors should be withheld prior to surgery, and surgery should be planned for at the end of the dosing cycle [35].
The International Consensus Meeting (ICM) on orthopedic infections, held in Philadelphia in 2018, adopted the ACR guidelines and graded the level of evidence as moderate [36]. The Swedish Association for Rheumatology has recommendations which are consistent with the ACR guidelines [37].

Guidelines on the prevention of SSI from the World Health Organization (WHO) state that perioperative discontinuation of methotrexate has no effect on the risk of SSI, and perioperative discontinuation of TNF-alpha inhibitors might have a benefit in reducing the SSI rate. The evidence for this is, however, considered to be of very low quality, and it is stated that "considering the scarce (or absent) evidence to support discontinuation of treatment (with anti-TNFs) and even potential harm it may cause (methotrexate), such as the risk of flare-up of the underlying disease(s) associated with the suspension of therapy, immunosuppressive medication should not be discontinued to prevent SSI" [38].

Since 2000 the departments of Orthopedics and Rheumatology at Skåne University Hospital in Lund, Sweden, have performed orthopedic surgery without 
interrupting methotrexate treatment. In 2006, new local guidelines were introduced, and discontinuation of TNFalpha inhibitors perioperatively in conjunction with orthopedic surgery in rheumatic patients was abolished. Data from a study conducted at our departments from 2003 to 2009 did not indicate that the perioperative use of TNF-alpha inhibitors or methotrexate was a clinically important risk factor for PJI [20].

The aim of the present study was to answer two questions: (i) What is the one-year incidence of SSI and PJI after total knee arthroplasty (TKA) and total hip arthroplasty (THA) in patients with inflammatory joint disease; and (ii) is there an association between the use of TNFalpha inhibitors, prednisolone, or methotrexate, and SSI or PJI rates?

\section{Methods}

This observational, nonrandomized retrospective singlecenter study used patient data from the departments of Rheumatology and Orthopedics at Skåne University Hospital in Lund, Sweden. The study was approved by the local ethics committee in Lund (Dnr 2016/880).

All patients above the age of 18 with an inflammatory joint disease who underwent primary TKA or THA between January 2006 and December 2015 were included in the study. Some patients had undergone more than one operation; the data analysis is based on cases (operations) and not individual patients. Information was collected from the local operation database. We included patients with an ICD-9 code for rheumatic disease of M058 or M059 (seropositive rheumatoid arthritis), M060 (seronegative rheumatoid arthritis), M069 (other rheumatoid arthritis), M073 (psoriatic and enteropathic arthropathies), or M080 (juvenile arthritis). The diagnosis was validated by crosschecking patients' medical records. If the patient had been given an ICD-9 code for inflammatory joint disease in conjunction with another surgery and the diagnosis could be validated, the patient was included in the study, even they had been given a different diagnosis by the operating surgeon at the time of the primary TKA or THA (most often osteoarthritis). Patients with the included diagnoses are those that can be considered for treatment with bDMARDs and by not only studying patients with RA a larger number of patients could be included.

Postoperative infections are generally classified according to the U.S. Centers for Disease Control and Prevention (CDC) 1992 definition of nosocomial SSIs [39], where infections are divided into (i) superficial incisional SSI involving the skin and subcutaneous tissue, (ii) deep incisional SSI involving deep soft tissue of the incision, and (iii) organ/space SSI involving any part of the anatomy (e.g., organs or spaces) other than the incision that was opened and manipulated during the operative procedure. In this study we used a modified definition of SSI, according to the one generally used in the field of orthopedics, where" deep incisional SSI" and "organ/ space SSI" are referred to together as PJI, and superficial incisional SSI is termed superficial SSI.

At least one of the following criteria was required for the diagnosis of PJI: (i) growth of identical microorganisms in at least two intraoperative cultures or a combination of preoperative aspiration and intraoperative cultures, (ii) presence of a sinus tract communicating with the prosthetic joint, (iii) presence of purulence without another known etiology surrounding the prosthetic device [40].

By definition, superficial SSI occurs within 30 days after surgery and PJI within 1 year. Patients were followed for 1 year after surgery, or until death or reoperation for a reason other than infection within 1year. With a longer follow-up time, one would expect to find a number of hematogenous infections, which was not our objective, since these cannot be related to medical treatment during the perioperative period. Patients were routinely contacted by a nurse 1 year after the operation and asked about postoperative complications such as infections. In 8 cases, data regarding one-year follow-up was missing, and the patients' medical records were scrutinized for medical contacts which could indicate a SSI.

In 43 cases data regarding ASA and in 20 cases data regarding BMI were missing and excluded from analysis. In five respectively six cases data regarding dosing of prednisolone and methotrexate were missing and excluded from analysis.

Due to the low expected rate of SSI a much higher number of patients, than treated at our center, would have to be included in a matched cohort study to receive enough statistical power.

\section{Statistics}

The association between infectious rate and medication was analyzed using chi- square test or Fisher's exact test when appropriate, using SPSS Statistics 23 for Windows. The significance level was set at $p<0.05$.

\section{Results}

A search of the local operations database yielded 522 operations during the study period. Twenty-eight operations in 24 patients were excluded from further analysis: 5 patients diagnosed with polymyalgia rheumatica, 10 with osteoarthritis, 1 with calcium pyrophosphate arthritis, 1 with spondyloepiphyseal dysplasia, and in 7 cases data regarding rheumatic diagnosis could not be found. After exclusions, data were collected on 494 operations involving 395 individual patients. Ninety-two patients had undergone more than one operation. 
Patient characteristics are described in Table 2. A majority of cases were female (76\%), and the mean age at the time of surgery was 62 years (range 18-89). TKA comprised $51 \%$ of procedures $(n=245)$. A majority of cases had RA (69\%), followed by juvenile idiopathic arthritis (JIA) (12\%). The most frequently used DMARD was methotrexate $(55.5 \%)$, followed by TNF-alpha inhibitors (31.8\%). Patients taking both methotrexate and a TNFalpha inhibitor comprised $18.2 \%$ of the sample. Details on treatment are summarized in Table 3.

The total incidence of SSI was 3.8\% $(n=19)$. Of these, 12 were superficial SSI, yielding a rate of $2.4 \%$. All of these infections resolved after wound debridement and/ or antibiotic treatment.

There were seven cases of PJI, yielding a one-year rate of $1.4 \%$. All cases of PJI occurred after TKA, and there was a statistically significant difference in the rate of PJI depending on operating site $(p=0.015)$. One of the

Table 2 Patients characteristics. Values are number (percentage) unless otherwise indicated

\begin{tabular}{|c|c|}
\hline All & 494 \\
\hline Female & $377(76.3)$ \\
\hline $\mathrm{TKA}^{1}$ & $254(51.4)$ \\
\hline $\mathrm{THA}^{2}$ & $240(48.6)$ \\
\hline Age, by time of surgery, mean (range) & $62.4(18-89)$ \\
\hline \multicolumn{2}{|l|}{ ASA $^{3}$, valid no 451} \\
\hline ASA 1 & $9(2)$ \\
\hline ASA 2 & $268(59.4)$ \\
\hline ASA 3 & $172(38.1)$ \\
\hline ASA 4 & $2(0.4)$ \\
\hline $\begin{array}{l}\mathrm{BMI}^{4}, \mathrm{~kg} / \mathrm{m}^{2} \text {, valid no } 474 \text {, } \\
\text { mean (range) }\end{array}$ & $26.5(14.9-44.6)$ \\
\hline \multicolumn{2}{|l|}{ Diagnosis } \\
\hline Rheumatoid arthritis ${ }^{a}$ & $341(69)$ \\
\hline Psoriatic arthritis & $35(7)$ \\
\hline Spondyloarthritis incl. Ankylosing spondylitis ${ }^{b}$ & $29(5.9)$ \\
\hline Juvenile idiopathic arthritis ${ }^{c}$ & 59 (11.9) \\
\hline Other diagnosis $^{d}$ & $30(6.1)$ \\
\hline
\end{tabular}

${ }^{1}$ Total knee-arthroplasty, ${ }^{2}$ Total hip-arthroplasty, ${ }^{3}$ American Society of Anesthesiologists (ASA) Physical Status, ${ }^{4}$ Body mass index

${ }^{\text {a }}$ Seropositive rheumatoid arthritis $(n=283)$, seronegative rheumatoid arthritis $(n=58)$

${ }^{\mathrm{b}}$ Ankylosing spondylitis $(n=21)$, other specified inflammatory spondylopathies $(n=6)$, inflammatory spondylopathy, unspecified $(n=2)$

juvenile arthritis $(n=40)$, juvenile arthritis with systemic onset $(n=7)$, juvenile polyarthritis (seronegative) $(n=6)$, juvenile arthritis, unspecified $(n=4)$, pauciarticular juvenile rheumatoid arthritis $(n=2)$

dInflammatory polyarthropathy $(n=1)$, polyarthritis, unspecified $(n=4)$, other specified arthritis $(n=4)$, monoarthritis, not elsewhere classified $(n=2)$, systemic lupus erythematosus, unspecified $(n=5)$, systemic lupus erythematosus with organ or system involvement $(n=3)$, adult-onset Still disease $(n=2)$, Crohn's disease $(n=1)$, ulcerative colitis $(n=1)$, polymyositis $(n=1)$, systemic sclerosis $(n=2)$, other overlap syndrome $(n=1)$, arthritis unspecified $(n=1)$, systemic involvement of connective tissue, unspecified $(n=2)$
Table 3 Exposure. Values are number (percentage) unless otherwise indicated

\begin{tabular}{|c|c|}
\hline Prednisolone & $214(43.3)$ \\
\hline Prednisolone, dose mg/d, mean (valid no 489) & 5.5 \\
\hline \multicolumn{2}{|l|}{ Number of ongoing DMARDs ${ }^{1}$} \\
\hline 0 & $109(22.1)$ \\
\hline 1 & $243(49.2)$ \\
\hline 2 & $132(26.7)$ \\
\hline 3 & $10(2)$ \\
\hline $\mathrm{CDMARD}^{2}$ & $343(69.4)$ \\
\hline Methotrexate & $274(55.5)$ \\
\hline Methotrexate dose, mg/w, mean (valid no 488) & 16 \\
\hline cDMARD $^{2}$ other than methotrexate ${ }^{a}$ & $69(14)$ \\
\hline $\mathrm{bDMARD}^{3}$ & $193(39.1)$ \\
\hline TNF- alpha inhibitor ${ }^{b}$ & $157(31.8)$ \\
\hline bDMARD $^{3}$, other than TNF- alpha inhibitor ${ }^{c}$ & $36(7.3)$ \\
\hline Methotrexate and prednisolone & $124(25.1)$ \\
\hline Methotrexate and TNF- alpha inhibitor & $90(18.2)$ \\
\hline Methotrexate and prednisolone and TNF- alpha inhibitor & $40(8.1)$ \\
\hline
\end{tabular}

${ }^{1}$ Disease-modifying antirheumatic drug

${ }^{2}$ Conventional disease-modifying antirheumatic drug

${ }^{3}$ Biologic disease-modifying antirheumatic drug

a azathioprine $(n=9)$, sulfasalazine $(n=30)$, hydroxychloroquine $(n=26)$,

mycophenolate mofetil $(n=3)$ and leflunomide $(n=1)$

betanercept $(n=93)$, golimumab $(n=5)$, certolizumab $(n=12)$, infliximab $(n=$

$15)$, adalimumab $(n=32)$

c abatacept $(n=6)$, rituximab $(n=16)$, anakinra $(n=5)$, tocilizumab $(n=14)$ One patient did bilateral THA at the same session and was treated with both

anakinra and rituximab

patients who suffered a PJI had a hematogenous infection 11 months after surgery, but according to the design of the study this counted as an SSI.

One patient with PJI was treated with the TNF-alpha inhibitor etanercept, and 4 patients were treated with methotrexate. There was no statistically significant difference in the rate of infection between patients treated with a TNF-alpha inhibitor and those who were not ( $p=$ $0.44)$ or those treated with methotrexate $(p=1.0)$. No association could be found between PJI and prednisolone $(p=0.25)$, TNF-alpha inhibitor and methotrexate in combination $(p=1.0)$, methotrexate and prednisolone in combination $(p=1.0)$, TNF-alpha inhibitor, methotrexate and prednisolone in combination $(p=1.0)$, BMI ( $p=$ $0.19)$, or ASA-score $(p=0.44)$ (Table 4$)$. No correlation could be found between diagnosis and the rate of PJI or the total number of SSI. No correlation could be found between the total number of SSI and treatment with prednisolone, methotrexate, TNF-alpha inhibitors or a combination of these treatments (Table 4).

Five out of 7 PJI healed after treatment with debridement and antibiotics. Details on patients suffering PJI, including outcome are described in Table 5. 
Table 4 Periprosthetic joint infection (PJI) and all surgical site infections (SSI) in various subgroups

\begin{tabular}{|c|c|c|c|c|c|}
\hline & Total (n) & PJI (n) & $p$-value & all SSI (n) & $p$-value \\
\hline Female & 377 & 3 & & 14 & \\
\hline Male & 117 & 4 & $0.06^{\mathrm{a}}$ & 5 & $0.78^{b}$ \\
\hline \multicolumn{6}{|c|}{ Procedure } \\
\hline $\mathrm{TKA}^{1}$ & 254 & 7 & & 11 & \\
\hline $\mathrm{THA}^{2}$ & 240 & 0 & $0.015^{\mathrm{a}}$ & 8 & $0.33^{b}$ \\
\hline \multicolumn{6}{|c|}{ BMI $^{3}$, valid no 474} \\
\hline$<30$ & 368 & 4 & & 12 & \\
\hline$>30$ & 106 & 3 & $0.19^{\mathrm{a}}$ & 7 & $0.16^{b}$ \\
\hline
\end{tabular}

$\mathrm{ASA}^{4}$, valid no 451

$\begin{array}{llllll}\leq 2 & 277 & 3 & & 10 & \\ \geq 3 & 174 & 4 & 0.44^{\mathrm{a}} & 8 & 0.60^{\mathrm{b}}\end{array}$

Treatment

\begin{tabular}{|c|c|c|c|c|c|}
\hline Methotrexate & 274 & 4 & $1.0^{\mathrm{a}}$ & 12 & $0.49^{\mathrm{b}}$ \\
\hline TNF-alpha inhibitor & 157 & 1 & $0.44^{\mathrm{a}}$ & 5 & $0.60^{b}$ \\
\hline Prednisolone & 214 & 5 & $0.25^{\mathrm{a}}$ & 10 & $0.40^{\mathrm{b}}$ \\
\hline Methotrexate and prednisolone & 124 & 2 & $1.00^{\mathrm{a}}$ & 4 & $0.79^{\mathrm{a}}$ \\
\hline Methotrexate and TNF-inhibitor & 90 & 1 & $1.00^{\mathrm{a}}$ & 3 & $1.00^{\mathrm{a}}$ \\
\hline Methotrexate, TNF- inhibitor and prednisolone & 39 & 0 & $1.00^{\mathrm{a}}$ & 0 & $0.39^{\mathrm{a}}$ \\
\hline \multicolumn{6}{|l|}{ iagnosis } \\
\hline Rheumatoid arthritis & 341 & 6 & $0.45^{\mathrm{a}}$ & 16 & $0.21^{\mathrm{a}}$ \\
\hline Psoriatic arthritis & 35 & 1 & $0.40^{\mathrm{a}}$ & 2 & $0.64^{\mathrm{a}}$ \\
\hline Spondyloarthritis incl. Ankylosing spondylitis & 29 & 0 & $1.0^{\mathrm{a}}$ & 0 & $1.0^{\mathrm{a}}$ \\
\hline Juvenile idiopathic arthritis & 59 & 0 & $1.0^{\mathrm{a}}$ & 1 & $0.76^{a}$ \\
\hline Other diagnosis & 30 & 0 & $1.0^{\mathrm{a}}$ & 0 & $1.0^{\mathrm{a}}$ \\
\hline
\end{tabular}

${ }^{1}$ Total knee-arthroplasty, ${ }^{2}$ Total hip-arthroplasty, ${ }^{3}$ Body mass index, ${ }^{4}$ American Society of Anesthesiologists (ASA) Physical Status

${ }^{\text {a}}$ Fisher's exact test

${ }^{\mathrm{b}}$ Chi-square test

Table 5 Periprosthetic joint infection (PJI), individual cases $^{a}$

\begin{tabular}{|c|c|c|c|c|c|}
\hline Diagnosis & $\begin{array}{l}\text { Type of } \\
\text { surgery }\end{array}$ & Anti-rheumatic treatment & Infectious agents & Treatment of PJI & Outcome \\
\hline $\begin{array}{l}\mathrm{RA}^{\mathrm{b}} \text {, } \\
\text { seronegative }\end{array}$ & TKA & Methotrexate, prednisolone & S. aureus & $\begin{array}{l}\text { Debridement and } \\
\text { exchange of tibial insert }\end{array}$ & $\begin{array}{l}\text { Healed ( } 26 \text { months later re-infected } \\
\text { with the same bacteria) }\end{array}$ \\
\hline $\begin{array}{l}\text { RA }{ }^{\mathrm{b}}, \\
\text { seropositive }\end{array}$ & TKA $^{c}$ & $\begin{array}{l}\text { Etanercept, } \\
\text { methotrexate }\end{array}$ & $\begin{array}{l}\text { coagulase negative } \\
\text { staphylococcus (CNS) }\end{array}$ & Two-stage revision & Healed \\
\hline $\begin{array}{l}\mathrm{RA}^{\mathrm{b}} \text {, } \\
\text { seropositive }\end{array}$ & $T_{K A}{ }^{c}$ & Prednisolone, azathioprine & S. aureus & $\begin{array}{l}\text { Debridement and } \\
\text { exchange of tibial insert }\end{array}$ & $\begin{array}{l}\text { Failure (chronic infection treated } \\
\text { with suppressive antibiotics) }\end{array}$ \\
\hline $\begin{array}{l}\mathrm{RA}^{\mathrm{b}} \text {, } \\
\text { seropositive }\end{array}$ & $T_{K A}{ }^{c}$ & Methotrexate, prednisolone & B. fragilis & Antibiotics & Failure, amputation \\
\hline $\begin{array}{l}\mathrm{RA}^{\mathrm{b}} \text {, } \\
\text { seropositive }\end{array}$ & $T_{K A}^{c}$ & $\begin{array}{l}\text { Methotrexate, sulfasalazine, } \\
\text { hydroxychloroquine, prednisolone }\end{array}$ & S. mitis, S. hominis & $\begin{array}{l}\text { Debridement and } \\
\text { exchange of tibial insert }\end{array}$ & Healed \\
\hline $\begin{array}{l}\mathrm{RA}^{\mathrm{b}} \text {, } \\
\text { seropositive }\end{array}$ & $T_{K A}{ }^{c}$ & Prednisolone & $\begin{array}{l}\text { coagulase negative } \\
\text { staphylococcus (CNS) }\end{array}$ & $\begin{array}{l}\text { Debridement and } \\
\text { exchange of tibial insert }\end{array}$ & Healed \\
\hline PsA $A^{c}$ & $T_{K A}{ }^{c}$ & None & $\begin{array}{l}\text { coagulase negative } \\
\text { staphylococcus (CNS) }\end{array}$ & $\begin{array}{l}\text { Debridement and } \\
\text { exchange of tibial insert }\end{array}$ & Healed \\
\hline
\end{tabular}

${ }^{a}$ In order to not compromise patient confidentiality age and sex is excluded from the table. There were 4 males and 3 females and the mean age was 64 years (range 44-70)

${ }^{\mathrm{b}}$ Rheumatoid arthritis

cpsoriatic arthritis 
Four out of seven of patients with a PJI were male, although only $24 \%$ of the operations were performed on male patients. However, there was no statistically significant difference in the rate of PJI between men and women $(p=0.06)$ (Table 4).

Six patients died within 1 year of surgery. One patient died 20 days after surgery due to a gastrointestinal bleeding. Three patients died due to acute coronary syndrome, one due to a subarachnoid hemorrhage and one due to progressive dementia (Pick's disease). None of the deaths within 1 year of surgery could be linked directly to surgery or PJI.

Four patients underwent reoperation within 1 year of surgery. One patient was reoperated due to joint instability, two due to aseptic loosening of the prosthesis, and one patient due to fracture after a resurfacing hip arthroplasty.

\section{Discussion}

The main finding in this study is that among patients with inflammatory joint disease undergoing primary knee or hip arthroplasty no association could be found between and PJI, or SSI in general and continued treatment with TNF-alpha inhibitors. Neither was there any association between infection rate and treatment with prednisolone, methotrexate, or combinations of treatments.

A previous study at our center [20] showed an increased risk of SSI in orthopedic surgery in general amongst patients who continued treatment with TNFalpha inhibitors perioperatively compared to patients discontinuing medication; however, the finding was due to a very low incidence rate of SSI following foot surgery in the comparison group.

A meta analysis comparing continuation versus discontinuation of TNF-alpha inhibitors prior to orthopedic surgery favors discontinuation of bDMARDs [8], although the studies included are heterogeneous in terms of differing timing of treatment interruption and the variety of patients and operations included. Furthermore, the included studies were underpowered to detect small changes in infection rate.

As shown in Table 1, other studies on the influence of TNF-alpha inhibitors on infection rates comes to different conclusions. Seven studies showed a slight increase in PJI rate [13, 16-20, 22], while seven [10-12, 14, 15, $21,23]$ showed no increase or a decrease in PJI in patients treated perioperatively with TNF-alpha inhibitors. The studies included different types of surgery, some compared patients not treated with TNF-alpha inhibitors to those treated with TNF-alpha inhibitors, and some compared the results of patients who continued TNFalpha inhibitors prior to surgery versus those who discontinued. Furthermore, the timing of treatment interruption varied, all of which makes conclusions difficult.

The rate of PJI was $1.4 \%$ which is comparable to what have been found in other studies on subjects with rheumatic disease [31, 41].

The rate of PJI after TKA was $2.8 \%$. This is somewhat higher than the one-year incidence for revision due to infection of 1.7\% for TKAs performed between 2006 and 2011reported from the Swedish Knee Arthroplasty Register (SKAR) [42]. The majority of patients in SKAR have osteoarthritis, and patients with RA have previously been shown to have a increased risk for PJI compared to patients with osteoarthritis [41, 43].

None of the THAs performed in our study resulted in a PJI. The Swedish Hip Arthroplasty Register (SHPR) reported an re-operation rate due to infection of $1.2 \%$ following THA performed in Sweden between 2005 and 2008 [44]. The fact that the incidence rate of THA was lower than expected could be coincidental or it could be due to low number of procedures in this study, although the same pattern - a higher risk of revision in RA patients undergoing a TKA than a THA - has been showed previously [43].

In only one of the seven cases of PJI was the patient treated with a TNF-alpha inhibitor: in this case, etanercept in combination with methotrexate. In total, $157 \mathrm{pa-}$ tients were treated with a TNF-alpha inhibitor (31.8\%), which means that only $0.63 \%$ of patients treated with a TNF-alpha inhibitor suffered a PJI.

From 2003 to 2005, before the new policy of perioperative continuation of TNF-alpha inhibitors was introduced in our departments, only $0.6 \%$ of implant operations led to a PJI [20]. The present finding of $1.4 \%$ is higher than this very low incidence rate, but the very small number of cases makes interpretation difficult.

One patient with PJI suffered a hematogenous infection with Streptococcus mites 11 months after surgery. The fact that the infection occurred so long after surgery may suggest that the treatment at the time of surgery was not a significant contributor to the infectious outcome. Leaving out this infection, the total rate of PJI would have been $1.2 \%$.

Men were overrepresented in the group with PJI $(p=$ $0.06)$, which is consistent with previous findings $[23,28$, 29].

PJI is a serious complication of arthroplasty, and potential risk factors for infection should be eliminated prior to surgery whenever possible. With this in mind, the risk of flares in patients with rheumatic disease when discontinuing DMARD treatment should be carefully considered when deciding whether to continue or discontinue DMARD treatment prior to surgery. Although our center does not perioperatively discontinue TNF- 
alpha inhibitors prior to elective arthroplasty surgery, we do not apply this approach as a general rule for others DMARDs such as rituximab, tocilizumab, or JAK inhibitors, for which data is scarcer.

This is a single-center study, and the procedures were performed by a few experienced surgeons following the same routines throughout the study period. One-year follow-up was standardized via a telephone call, and data on perioperative medications were retrieved by one investigator $(\mathrm{YB})$ using medical records. There was little missing data (Table 3), mostly regarding dosing of methotrexate and prednisolone, which did not affect the result.

The limitations of this study include its observational and descriptive nature, insofar as it did not include a control group pausing treatment with bDMARDs. The overall rate of SSI, including PJI, was low, and it is thus underpowered, as are all other similar investigations. Based on the available data, presented in Table 1, it seems likely that treatment with TNF-alpha inhibitors per se confers a somewhat increased risk of PJI. The importance of stopping treatment perioperative is unclear. In fact, it is not likely that a randomized, controlled trial of stopping bDMARDs perioperatively will be performed, as this would require a very large number of procedures. Assuming a general PJI incidence of $2 \%$, a clinical trial would have to include more than 21,000 procedures within each group (continuation versus cessation of bDMARD perioperatively) to detect a $20 \%$ increase of PJI incidence with a power of $80 \%$. Furthermore, each bDMARD would require its own trial.

\section{Conclusions}

We found no signs of increased PJI risk despite perioperative DMARD treatment in patients with inflammatory joint disease undergoing elective TKA or THA. Our center's policy of perioperative continuation of TNFalpha inhibitors and most other bDMARDs will remain unchanged. Larger, preferably multi-center, studies are needed to elucidate the role, if any, of perioperative treatment cessation in reducing PJI rates.

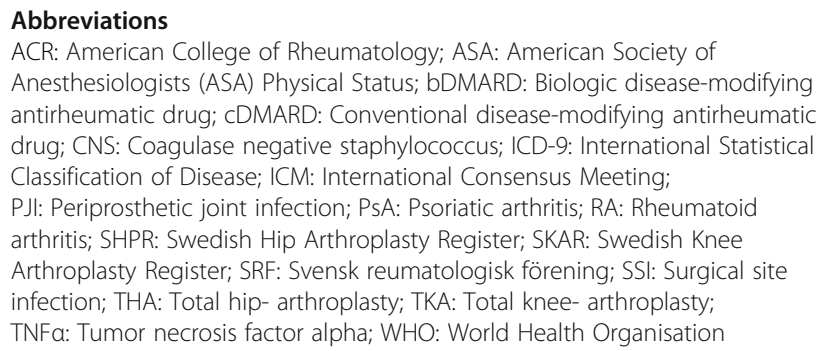

\section{Acknowledgements}

We thank Jan- Åke Nilsson for help with the statistical work and Martin Sundberg for help with extraction of data from OrtReg (the local patient registry for orthopaedic surgery.

\section{Authors' contributions}

All authors contributed to the design of the study. YB and MK collected data which was analyzed by YB and AST. YB drafted the article with critical revisions from AS, AG and MK. All authors contributed to interpretation and approved the final manuscript.

\section{Funding}

This study was sponsored by a grant from Kockska stiftelsen. The sponsor had no role in study design, the collection of data, analysis and interpretation of the data or in the writing of the article.

\section{Availability of data and materials}

The datasets used and/or analysed during the current study will be available from the corresponding author on reasonable request.

\section{Ethics approval and consent to participate}

This study was approved by the local ethics committee in Lund (Dnr 2016/ 880).

\section{Consent for publication}

not applicable.

\section{Competing interests}

The authors declare that they have no competing interests.

\section{Author details}

'Department of Rheumatology, Skåne University Hospital, SE-221 85 Lund, Sweden. ${ }^{2}$ Department of Clinical Sciences, Section of Rheumatology, Lund University, Lund, Sweden. ${ }^{3}$ Department of Orthopaedics, Skåne University Hospital, SE-221 85 Lund, Sweden. ${ }^{4}$ Department of Clinical Sciences, Section of Orthopaedics, Lund University, Lund, Sweden.

Received: 1 December 2019 Accepted: 24 June 2020

Published online: 29 June 2020

References

1. Fevang BTS, Lie SA, Havelin LI, Engesaeter LB, Furnes O. Reduction in orthopedic surgery among patients with chronic inflammatory joint disease in Norway, 1994-2004. Arthritis Care Res. 2007;57(3):529-32.

2. Jämsen E, Virta L, Hakala M, Kauppi MJ, Malmivaara A, Lehto MUK. The decline in joint replacement surgery in rheumatoid arthritis is associated with a concomitant increase in the intensity of anti-rheumatic therapy. Acta Orthop. 2013;84(4):331-7.

3. Louie GH, Ward MM. Changes in the rates of joint surgery among patients with rheumatoid arthritis in California, 1983-2007. Ann Rheum Dis. 2010; 69(5):868-71.

4. Nystad TW, Fenstad AM, Furnes O, Fevang BT. Predictors for orthopaedic surgery in patients with rheumatoid arthritis: results from a retrospective cohort study of 1010 patients diagnosed from 1972 to 2009 and followed up until 2015. Scand J Rheumatol. 2018;47(4):282-90.

5. Skyttä ET, Honkanen PB, Eskelinen A, Huhtala H, Remes V. Fewer and older patients with rheumatoid arthritis need total knee replacement. Scand J Rheumatol. 2012;41(5):345-9.

6. Weiss RJ, Ehlin A, Montgomery SM, Wick MC, Stark A, Wretenberg P. Decrease of RA-related orthopaedic surgery of the upper limbs between 1998 and 2004: data from 54579 Swedish RA inpatients. Rheumatology. 2008:47(4):491-4.

7. Cordtz RL, Hawley S, Prieto-Alhambra D, Højgaard P, Zobbe K, Overgaard S, Odgaard A, Kristensen LE, Dreyer L. Incidence of hip and knee replacement in patients with rheumatoid arthritis following the introduction of biological DMARDs: an interrupted time-series analysis using nationwide Danish healthcare registers. Ann Rheum Dis. 2018;77(5):684-9.

8. Clay M, Mazouyes A, Gilson M, Gaudin P, Baillet A. Risk of postoperative infections and the discontinuation of TNF inhibitors in patients with rheumatoid arthritis: a meta-analysis. Joint Bone Spine. 2016;83(6):701-5.

9. Mabille C, Degboe Y, Constantin A, Barnetche T, Cantagrel A, RuyssenWitrand A. Infectious risk associated to orthopaedic surgery for rheumatoid arthritis patients treated by anti-TNFalpha. Joint Bone Spine. 2017;84(4):441-5. 
10. Bibbo C, Goldberg JW. Infectious and healing complications after elective orthopaedic foot and ankle surgery during tumor necrosis factor-alpha inhibition therapy. Foot Ankle Int. 2004;25(5):331-5.

11. Talwalkar SC, Grennan DM, Gray J, Johnson P, Hayton MJ. Tumour necrosis factor alpha antagonists and early postoperative complications in patients with inflammatory joint disease undergoing elective orthopaedic surgery. Ann Rheum Dis. 2005;64(4):650-1.

12. Wendling D, Balblanc J-C, Brousse A, Lohse A, Lehuede G, Garbuio P, Toussirot $E$, Auge $B$, Jacques D. Surgery in patients receiving anti-tumour necrosis factor alpha treatment in rheumatoid arthritis: an observational study on 50 surgical procedures. Ann Rheum Dis. 2005;64(9):1378-9.

13. Giles JT, Bartlett SJ, Gelber AC, Nanda S, Fontaine K, Ruffing V, Bathon JM. Tumor necrosis factor inhibitor therapy and risk of serious postoperative orthopedic infection in rheumatoid arthritis. Arthritis Rheum. 2006;55(2):333-7.

14. Broeder AA, Creemers MCW, Fransen J, de Jong E, de Rooij D-JR, Wymenga A, de Waal-Malefijt M, van den Hoogen FH. Risk factors for surgical site infections and other complications in elective surgery in patients with rheumatoid arthritis with special attention for anti-tumor necrosis factor: a large retrospective study. J Rheumatol. 2007;34(4):689-95.

15. Ruyssen-Witrand A, Gossec L, Salliot C, Luc M, Duclos M, Guignard S, Dougados M. Complication rates of 127 surgical procedures performed in rheumatic patients receiving tumor necrosis factor alpha blockers. Clin Exp Rheumatol. 2007;25(3):430-6.

16. Gilson M, Gossec L, Mariette X, Gherissi D, Guyot M-H, Berthelot J-M, Wendling D, Michelet C, Dellamonica P, Tubach F, Dougados M, Salmon D. Risk factors for total joint arthroplasty infection in patients receiving tumor necrosis factor a-blockers: a case-control study. Arthritis Res Therapy. 2010;12(4):R145.

17. Kawakami K, Ikari K, Kawamura K, Tsukahara S, Iwamoto T, Yano K, Sakuma Y, Tokita A, Momohara S. Complications and features after joint surgery in rheumatoid arthritis patients treated with tumour necrosis factor-alpha blockers: perioperative interruption of tumour necrosis factor-alpha blockers decreases complications? Rheumatology. 2010;49(2):341-7.

18. Suzuki M, Nishida K, Soen S, Oda H, Inoue H, Kaneko A, Takagishi K, Tanaka T, Matsubara T, Mitsugi N, Mochida Y, Momohara S, Mori T, Suguro T. Risk of postoperative complications in rheumatoid arthritis relevant to treatment with biologic agents: a report from the committee on arthritis of the Japanese Orthopaedic association. J Orthop Sci. 2011;16(6):778-84

19. Momohara S, Kawakami K, Iwamoto T, Yano K, Sakuma Y, Hiroshima R, Imamura H, Masuda I, Tokita A, Ikari K. Prosthetic joint infection after total hip or knee arthroplasty in rheumatoid arthritis patients treated with nonbiologic and biologic disease-modifying antirheumatic drugs. Mod Rheumatol. 2011;21(5):469-75.

20. Berthold E, Geborek P, Gülfe A. Continuation of TNF blockade in patients with inflammatory rheumatic disease. An observational study on surgical site infections in 1,596 elective orthopedic and hand surgery procedures. Acta Orthop. 2013;84(5):495-501.

21. Tada M, Inui K, Sugioka Y, Mamoto K, Okano T, Kinoshita T, Hidaka N, Koike T. Delayed wound healing and postoperative surgical site infections in patients with rheumatoid arthritis treated with or without biological disease-modifying antirheumatic drugs. Clin Rheumatol. 2016;35(6):1475-81.

22. Hayashi S, Hashimoto S, Takayama K, Matsumoto T, Takebe K, Terashima Y, Kuroda R, Sakai Y, Ishida K, Nishida K. Risk factors for late deep infection after total hip arthroplasty in patients with rheumatoid arthritis. Acta Reumatol Port. 2017;42(2):150-4.

23. Salt E, Wiggins AT, Rayens MK, Morris BJ, Mannino D, Hoellein A, Donegan RP, Crofford LJ. Moderating effects of immunosuppressive medications and risk factors for post-operative joint infection following total joint arthroplasty in patients with rheumatoid arthritis or osteoarthritis. Semin Arthritis Rheum. 2017:46(4):423-9.

24. Grennan DM. Methotrexate and early postoperative complications in patients with rheumatoid arthritis undergoing elective orthopaedic surgery. Ann Rheum Dis. 2001;60(3):214-7.

25. Dalury DF, Pomeroy DL, Gorab RS, Adams MJ. Why are total knee arthroplasties being revised? J Arthroplast. 2013;28(8 Suppl):120-1.

26. Portillo ME, Salvadó M, Alier A, Sorli L, Martínez S, Horcajada JP, Puig L. Prosthesis Failure Within 2 Years of Implantation Is Highly Predictive of Infection. Clin Orthop Relat Res. 2013;471(11):3672-8.

27. Castano-Betancourt MC, Fruschein Annichino R, de Azevedoe Souzamunhoz M, Gomes Machado E, Lipay MV, Marchi E. Identification of high-risk groups for complication after arthroplasty: predictive value of patient's related risk factors. J Orthop Surg Res. 2018;13(1):328.
28. Kong L, Cao J, Zhang Y, Ding W, Shen Y. Risk factors for periprosthetic joint infection following primary total hip or knee arthroplasty: a meta-analysis. Int Wound J. 2017;14(3):529-36.

29. Kunutsor SK, Whitehouse MR, Blom AW, Beswick AD, Team INFORM. Patientrelated risk factors for Periprosthetic joint infection after Total joint Arthroplasty: a systematic review and Meta-analysis. PLoS One. 2016;11(3):e0150866.

30. Tande AJ, Patel R. Prosthetic joint infection. Clin Microbiol Rev. 2014;27(2):302-45.

31. Bongartz T, Halligan CS, Osmon DR, Reinalda MS, Bamlet WR, Crowson CS, Hanssen AD, Matteson EL. Incidence and risk factors of prosthetic joint infection after total hip or knee replacement in patients with rheumatoid arthritis. Arthritis Rheum. 2008;59(12):1713-20.

32. Bozic KJ, Lau E, Kurtz S, Ong K, Berry DJ. Patient-related risk factors for postoperative mortality and periprosthetic joint infection in medicare patients undergoing TKA. Clin Orthop Relat Res. 2012;470(1):130-7.

33. Jover-Saénz A, Barcenilla-Gaite F, Torres-Puig-Gros J, Prats-Gispert L, GarridoCalvo S, Porcel-Pérez JM. Risk factors for total prosthetic joint infection. Case-control study. Med Clin. 2007;128(13):493-4.

34. Schrama JC, Fenstad AM, Dale H, Havelin L, Hallan G, Overgaard S, Pedersen AB, Kärrholm J, Garellick G, Pulkkinen P, Eskelinen A, Mäkelä K, Engesæter LB, Fevang BT. Increased risk of revision for infection in rheumatoid arthritis patients with total hip replacements. Acta Orthop. 2015;86(4):469-76.

35. Goodman SM, Springer B, Guyatt G, Abdel MP, Dasa V, George M, GewurzSinger O, Giles JT, Johnson B, Lee S, Mandl LA, Mont MA, Sculco P, Sporer S, Stryker L, Turgunbaev M, Brause B, Chen AF, Gililland J, Goodman M, HurleyRosenblatt A, Kirou K, Losina E, MacKenzie R, Michaud K, Mikuls T, Russell L, Sah A, Miller AS, Singh JA, Yates A. 2017 American College of Rheumatology/American Association of hip and Knee Surgeons Guideline for the perioperative Management of Antirheumatic Medication in patients with rheumatic diseases undergoing elective Total hip or Total knee Arthroplasty: ACR/AAHKS guideline for perioperative management. Arthritis Care Res. 2017:69(8):1111-24

36. Iorio R, Cizmic Z, Feng JamesE, Kunutsor S. Hip and Knee. ICM Philly. Available from: https://icmphilly.com/document/icm-2018-hip-and-kneedocument/ [Accessed: 8th February 2019].

37. Baecklund $E$, Innala L, Wiberg K, Kapetanovic M, Kvarnström M, Larsson K. Hantering av antireumatiska läkemedel vid elektiv reumakirugi. Svensk Reumatologisk Förening. Available from: http://svenskreumatologi.se/srfsriktlinjer/ [Accessed: 22nd September 2018].

38. Allegranzi B, Bischoff $P$, Kubilay Z, de Jonge $S$, Zayed B, Abbas M, Boermeester MA, Dellinger EP, Egger M, Gastmeier P, Guirao X, Ren J, Pittet D, Solomkin JS. WHO | Global guidelines on the prevention of surgical site infection. WHO. Available from: http://www.who.int/gpsc/ssi-preventionguidelines/en/ [Accessed: 7th October 2018].

39. Horan TC, Gaynes RP, Martone WJ, Jarvis WR, Emori TG. CDC definitions of nosocomial surgical site infections, 1992: a modification of CDC definitions of surgical wound infections. Infect Control Hosp Epidemiol. 1992;13(10):606-8.

40. Osmon DR, Berbari EF, Berendt AR, Lew D, Zimmerli W, Steckelberg JM, Rao N, Hanssen A, Wilson WR. Diagnosis and management of prosthetic joint infection: clinical practice guidelines by the Infectious Diseases Society of America. Clin Infect Dis. 2013;56(1):e1-e25.

41. Cordtz RL, Zobbe K, Højgaard P, Kristensen LE, Overgaard S, Odgaard A, Lindegaard $H$, Dreyer L. Predictors of revision, prosthetic joint infection and mortality following total hip or total knee arthroplasty in patients with rheumatoid arthritis: a nationwide cohort study using Danish healthcare registers. Ann Rheum Dis. 2018;77(2):281-8.

42. Sundberg M, Lidgren L, W-Dahl A, Robertsson O. Årsrapport 2013, Svenska knäprotesregistret. Available from: http://www.myknee.se/pdf/SKAR2013_Sv1.1.pdf.

43. Schrama JC, Espehaug B, Hallan G, Engesæter LB, Furnes O, Havelin LI, Fevang BT. Risk of revision for infection in primary total hip and knee arthroplasty in patients with rheumatoid arthritis compared with osteoarthritis: a prospective, population-based study on 108,786 hip and knee joint arthroplasties from the Norwegian Arthroplasty register. Arthritis Care Res. 2010;62(4):473-9.

44. Garellick G, Rogmark C, Kärrholm J, Rolfson O. Swedish Hip Arthroplasty Register Annual Report 2012. Available from: https://registercentrum.blob. core.windows.net/shpr/r/Annual-report-2012-HJBqtLpig.pdf.

\section{Publisher's Note}

Springer Nature remains neutral with regard to jurisdictional claims in published maps and institutional affiliations. 